\title{
The Interrelation between Local Government of Kapuas Hulu Regency and Breeders in Developing the Breeding of Super Red Arowana
}

\author{
Firmansyah $^{1, a)}$ Hermin Indah Wahyuni ${ }^{2}$ Alia Bihrajihant Raya, ${ }^{3)}$ \\ 1,2,3 Universitas Gadjah Mada \\ a) author correspondence: acc.firmans@gmail.com
}

DOI: https://doi.org/10.18196/jkm.112026

Article Info

Article history:

Received 30 Aug 2019

Revised 21 Oct 2019

Accepted 13 Nov 2018

\section{ABSTRACT}

Super Red Arowana breeding activities have the potential to be developed for community and regional improvement in Kapuas Hulu Regency. Initiatives to establish breeding activities through programs that are expected to be a source of regional income and to create suitable self supports for breeders are still experiencing some obstacles due to the lack of interaction on communication and distribution of information between the local government of Kapuas Hulu and the breeders that are not transparent, equal, and smooth. This study aimed to find the interrelation of the Kapuas Hulu local government with the breeders in the development of Super Red Arowana captivity activities and the efforts of the stakeholders in improving interrelation through communication accommodation studies. This study uses a qualitative method for explanative purposes. The results showed that a problem in the internal environment Kapuas Hulu local government and the breeder impinge on the interrelation of them. The efforts of both parties in improving interrelation through joint media have not shown adequate results due to the lack of full and mutual recognition. The local government of Kapuas Hulu and the breeders in the process of accommodating communication have adopted not only convergence but also divergence adaptation.

Keywords: Super Red Arowana; Kapuas Hulu Regency; Interrelation; Convergence; Divergence

\section{ABSTRAK}

Kegiatan penangkaran Arwana Super Merah memiliki potensi untuk dikembangkan guna pembangunan masyarakat dan daerah di Kabupaten Kapuas Hulu. Inisiatif untuk mengembangkan kegiatan penangkaran melalui program yang diharapkan dapat menjadi sumber pendapatan daerah dan dapat menciptakan kemandirian bagi penangkar masih menemui kendala berupa minimnya interaksi komunikasi dan distribusi informasi diantara Pemerintah daerah Kabupaten Kapuas Hulu dengan penangkar secara terbuka, merata, dan lancar. Penelitian ini bertujuan untuk mengetahui bagaimana interelasi pemerintah daerah Kabupaten Kapuas Hulu dengan penangkar dalam pengembangan kegiatan penangkaran Arwana Super Merah serta upaya kedua belah pihak dalam memperbaiki interelasi melalui kajian komunikasi akomodasi. Penelitian ini menggunakan metode kualitatif untuk tujuan eksplanatif. Hasil penelitian menunjukkan adanya permasalahan pada lingkungan internal Pemerintah Daerah Kabupaten Kapuas Hulu dengan Penangkar turut mempengaruhi terhambatnya interelasi kedua belah pihak. Upaya kedua belah pihak dalam memperbaiki interelasi melalui medium bersama belum menunjukkan hasil yang memadai dikarenakan minimnya pengakuan bersama secara mutual dan penuh. Pemerintah Daerah Kabupaten Kapuas Hulu dengan Penangkar pada proses komunikasi akomodasinya disatu sisi sudah mengadopsi adaptasi konvergensi, namun disisi yang lain juga mengadopsi adaptasi divergensi. 


\section{INTRODUCTION}

The role of communication in the developmental project is a set of variables that figure in creating prevalent, just, and inclusive development to establish a prosperous society and region. Ideally, that communication and development should have been realized by the Local Government of Kapuas Hulu regency (PDKK), whether in terms of the internal and external aspects, as ordered by Law Number 22 of 1999 about regional autonomy. The realization is expected to run through society's empowerment, both programs that have been determined as a routine agenda and those that are still in the potential monitoring phase. One of the local lists that have been monitored by PDKKH is the breeding activity of Super Red Arowana (ASM).

The breeding activity of Super Red Arowana (ASM) posses a well and potential prospect to be developed because of high selling price, easiness to trade, stability in the market, as not like other decorative fishes which are influenced by seasonal aspects, and be able to harvested at any time even when it is still tillers. The market target of ASM for West Kalimantan territory is planned almost in all regencies. Moreover, the targets for national are Java, Sumatra, and Sulawesi, while for international are Malaysia, Singapore, Vietnam, Thailand, Hong Kong, Taiwan, Macau, South Korea, Japan, and China. Japan and China are the most significant destination market with nearly $80 \%$ of all exports and they especially demand it (BKIPM Pontianak, 2018).

The breeding activity has sequel effects such as the availability of new jobs for non-breeders, whether with a short-term or long-term scale. Some examples of the jobs are fishpond excavation services, fish feed supply cultivation, fish natural feed supply services, fish guarding and pond maintenance services, fish storage services, land leasing services for breeding and fish distribution services. The other potency comes from the geographical aspect of Kapuas Hulu Regency (KKH), which is a part of the National Parks of Sentarum Lake. It enables the majority of the KKH territory peat forest waters with a chalky soil base that is very rich in equatorial local nuftah plasma with the highest grade (BKSDA West Kalimantan Province, 2018). This is the reason the creation of endemic habitats for ASM takes place on freshwater waters like rivers and lakes in KKH. These facts state that not all regions of West Kalimantan Province are compatible with the breeding of ASM because this kind of fish is highly sensitive to the temperature and condition of the water. Therefore, the geographical shape of KKH causes this regency as the breeding center of ASM.

Those potencies, eventually, encouraged PDKKH's to create Super Arowana Fish Breeders (PIASM) to realize breeding activity as one of the development programs of society and regions in KKH. By this implementation of ASM breeding activity as one of the programs, PDKKH expects that it can contribute to locally-generated revenue, while PIASM is hopefully able to stimulate better development of society's breeding activity. This is because even though the breeding activity of ASM had been existed and survived since a long time ago until today, its development has not been thoroughly able to make ASM breeders self-sustained and prosperous. In the long run, those initiatives could not be concretely implemented and only became an idea between PDKKH and PIASM. Only in 2012, the realization of that idea could be manifested by distributing mother fishes of ASM as an initial grant from Fishery Affairs to the breeders.

Nevertheless, since the third quarter of 2012, the initial grant was not distributed anymore (Fishery Affairs of Kapuas Hulu regency, 2018). The reason is that the initiatives to realize the program of breeding activity should put up with obstacles, ranging from low synergy, interaction, communication and information distribution flow between PDKKH and PIASM. PDKKH, on the one hand, assessed that PIASM was less cooperative in sharing information about the details of technical breeding and the details of physical and non-physical aspects of reproduction. On the other hand, PIASM considered that PDKKH was less open about the information of access, requirement, and arrangement of capital assistance, and the facilities of breeding activity of ASM.

Those problems affected and obstructed the interrelation process between PDKKH and PIASM, which then implicated on the failure of both camps in realizing ASM breeding activity. The low of insights and ideas to identify the aspects of necessity and problem to provide assistance, planning 
preparation, purpose determination, details of main tasks and implementing actor's functions, and operational system of implementation to developing breeding activity are considered risky to manifested. The risks are the inaccuracy of application and target that will waste energy, thought, and budget. Another consequence for both are, on the one hand, PDKK failed to make ASM breeding activity to be one of the locally-generated revenues of $\mathrm{KKH}$, while, on the other hand, PIASM failed to develop their breeding activity. The minimum assistance access given by PDKKH to PIASM in the forms of maintaining quality, temperature, water $\mathrm{pH}$ and quality feeds, had impacts on the fish color fading, the hampered fish growth, and the ability of fish to lay eggs normally. The hampered interrelation between PDKKH and PIASM had obviously brought negative impacts for both in developing breeding activity to enhance the prosperity of breeders, society, and region. The absence of meaning and recognition in a shared social space between PDKKH and PIASM about breeding activity had eventually caused un-ideal interrelation between the two parties.

The previous research focused on the interrelation between the agent and the subject of development. It was done by Handaka and Hermin (2017) which studied the interrelation of counseling and livestock subsystem in a system of governmental communication showed the significant role of enhancing interrelation both parties in producing and reproducing the information. Communication is an important instrument to support the process of interrelation because the interrelation strongly depends on the happening of transmitting information and interaction that has a role in bridging diversity (Handaka and Hermin, 2017). The result of that research demonstrated that the interrelation was discussed by two formal groups horizontally in the internal environment of the same group, while this research will focus on the interrelation, which is studied from two different groups, formal and informal groups, diagonally. Based on the explanation above, the research aims to describe the interrelation between PDKKH and PIASM in developing the breeding of ASM and discussing the efforts of PDKKH and PIASM in improving and interlacing the interrelation.

The context of communication in the interrelation is built based on communication relations between individual and individual, group and group, organization, and society (Hertanto, et al., 2016). In the process, the actors of interrelation sometimes stay in different positions. At times they can be positioned as a communicator, but at any time they can also be placed as a communicant, depending on the source of information being distributed comes from. This is caused by the existence of dependency and necessity toward the data from both parties (Buckley in Pandjaitan, 2015). The obstacles of the fluency of communication interaction are the character or mindset that has been entrenched, values, physical space among individuals, perception, and motivation, emotional interpretation, which can obstruct the process of adaptation and harmonization, and experience and language. Those obstacles can affect the infrequent communication interaction and information distribution, which need a long time and complicated in the process of delivering (Rahmanto, 2004).

Law Number 25 of 1999 stated that local government and society are expected to own capability to execute mutual synergy through communication interaction and information exchange in identifying and managing the potencies of local resources to be utilized effectively and efficiently (Nurdin, et al., 2014). Santosa (2014) uttered that some critical points that need to be implemented to enhance synergy between actors and subject of development can be in the forms of the effectivity of communication roles, information distribution, and utilization of communication channels as a bridge of social information, mainly via opinion leaders. The opinion leaders possess a significant position and role because they are the people who function to influence other people systematically on some specific issues. Generally, the success of the communication process -delivering and implementing the information-is determined by the support of opinion leaders. However, what should be considered too is the existence of opinion leaders who abuse their role and position to influence and realize the primary information that is based on their individual interests (Wahyuni, 2007).

The process of society and regional development based on local resources is not only the responsibility of government and culture but also the involvement of other parties such as private sectors and local organizations. Raya (2016), in his research, stated that it is important to take consideration from various groups which lead to different participation. A group that is established by external agents without involving local organizations will be weak because each function will not work. Besides, the local organization and group, structurally and in work experience, have been enough established. As a result, the attempt to develop society and region will be only about enhancement and development.

Society and regional development can be manifested by meeting agents and the subject of development directly. In that vein, conformity between physical and spiritual aspects of progress is 
required. By doing so, the process of development communication can be conformable, operated, and generate consensus without harming any parties (Choirul, et al., 2018). According to Moemeka in Subejo (2016), the role of communication between agent and subject of development figure in transforming social change, with quality of life and social justice, and preserve established social norms that are in line with the regional development values.

One of the requirements to manifest an effective development of society and region is through the communication accommodation approach in the interrelation process between agent and subject of development. This is because, according to the perspective of communication science, communication accommodation is vital to see reciprocal interrelation. Kartikawangi (2013) uttered that, in her research that focused on the interrelation among interest stakeholders, communication accommodation is profoundly fundamental for the strategy and implementation of corporate social responsibility to support business continuity. That research exhibited that an accommodation communication approach can be applied to investigate meaning construction in inter-groups interrelation. The Kartikawangi's investigation result is much appealing because the accommodation communication approach has not been examined its implementation on the interrelation between agent and subject of development, such as between Local Government of Kapuas Hulu regency and breeders of ASM.

\section{METHODS}

The character of this research was explanative with a qualitative approach. The purpose of explanative can be understood as an effort to overcome investigated problems, find an explanation about the reason for an incident or phenomenon, and explain the background of a particular social condition by the description of cause-effect relation (Neuman, 2013). This research prioritized the depth of data and the informants were chosen purposively. As for PDKKH, the informants came from Fishery Affairs as Regional Apparatus Organization (OPD) leading sector of breeding activity and Development Planning Agency at Sub-National Level (Bappeda). They had a strategic role in stimulating activity to be a program. As to PIASM, the informants came from the breeders in South Putussibau District, Suhaid District, and Semitau District, Kapuas Hulu Regency. The locations of this research were selected because KKH is a central region of ASM breeding development. The election of PIASM informants from those three districts is motivated by the largest area of breeder's fishpond with an average of 10,31 hectares and the highest number of fishpond amount with an average of 82 fishponds in which each fishpond's wide is 10x30m in Kapuas Hulu Regency. Their breeding activity inherits hereditary from their family (Fishery Affairs of Kapuas Hulu Regency, 2018).

The data was collected by applying participative observation, interview, documentation, and study of literature. Collecting data was executed during pre-field investigation in September 2018 and March 2019 and during field research in June 2019. Data validation used triangulation of sources and techniques. The analysis of data was undertaken during field study by sharpening research focus, developing analytical questions, noting research's thoughtful comments about findings in the field, and examining the relationship between subject and research focus. Besides, the data analysis was also done after leaving the area by data reduction, data presentation, and data verification.

Content of reseach methods use Microsoft Word style: paragraph.

\section{RESULT AND DISCUSSION}

The research showed that the actors of PDKKH have significant roles in the ASM breeding activity; aside from Fishery Affairs and Development Planning Agency at Sub-National Level (BAPPEDA), there are other actors like Department of Youth, Sport, and Tourism which promoted the ASM breeding activity, and Regional Finance Agency (BKD) exerting a role to assign the amount of allocation that could be spent for assigned programs. The line of communication and coordination among actors in the internal environment of PDKKH in the breeding activity of ASM can be viewed in Figure 1. 


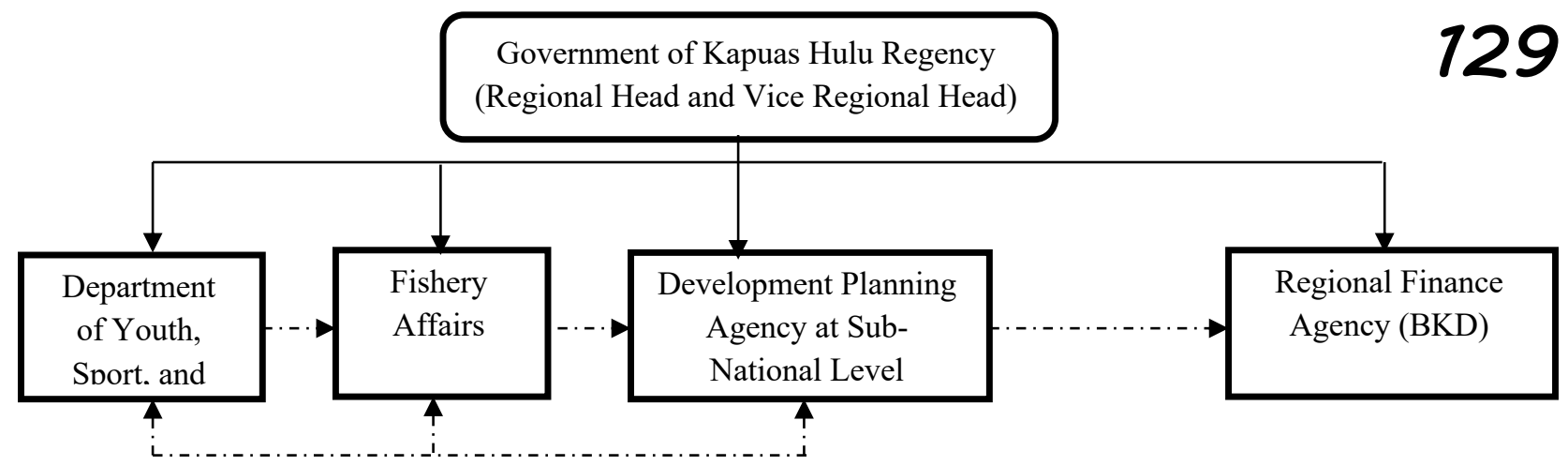

1. Facts and data collection of ASM breeding activity by Fishery Affairs 2. The reconciliation and identification of facts and data collectively by Fishery Affairs, Department of Tourism, BAPPEDA through Focus Group Discussion (Discussion Forum of OPD) in order to realize ASM breeding activity to be a program of society development 3 . The proposal verification of breeding activity of ASM to be a program by BAPPEDA, Fishery Affairs, and Department of Tourism 4. Program counseling and socialization to the breeders as targeted subjects by Fishery Affairs, Department of Tourism, and BAPPEDA.

Adjusting the submission of the proposed program budget ceiling as the result of a consensus between Department of Tourism, Fishery Affairs, BAPPEDA and Regional Finance Agency (BKD) that has an authority to assign budget ceiling of Kapuas Hulu Regencv

Figure 1. The line of communication and coordination among actors in the internal environment of PDKKH in the breeding activity of ASM (Source: Primary data and secondary data, 2019)

In the breeding activity, the breeders, based on Ministerial Regulation KP/No.35/2015, are classified into small breeders and big breeders depending on the large of land and fishpond they own. A big breeder has an area with a minimum 1 hectare wide for about 5-10 fishponds, while a small breeder is less than that. The research found that those classifications were based on the ownership of the facility, the availability of seed, feed, the quality of broodstock and yields, the line of marketing distribution, the level of consumer orders, and the legality of breeding activity. The research demonstrated that the actors of PIAS had roles in the ASM breeding activity which consisted of association parties, big breeders, and small breeders. The line of communication and coordination among actors in the internal environment of PIASM in the ASM breeding activity can be seen in Figure 2 . 


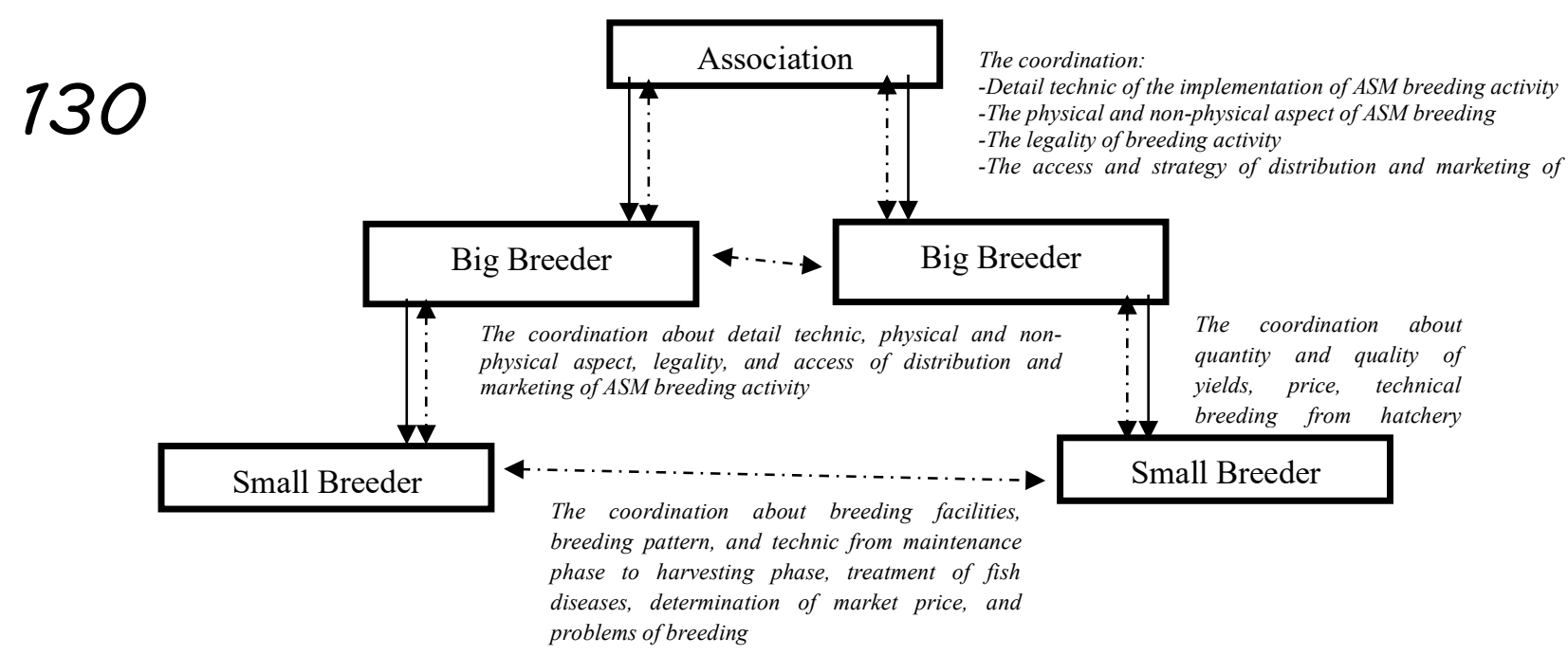

Figure 2. The line of communication and coordination among actors in the internal environment of PIASM in the ASM breeding activity. Source: Primary data, 2019

From the research, it is discovered that the interrelation process between PDKKH and PIASM should be realized through facilitation of Department of Investment and One-Stop Integrated Services in the accompaniment activity of PIASM by BKSDA, accompaniment forum held by Fishery Affairs with PIASM, promotion facilitation with PIASM through contest and ASM exhibition which was firstly conducted in 2018, and make it as one of the yearly sub-programs of Tourism Sub-Field, Department of Youth, Sport, and Tourism and the attempt to increase PIASM participation through its involvement in a forum namely Budget Discussion Meeting (Musrenbang) which is routinely held three time a year by Development Planning Agency at Sub-National Level (BAPPEDA). The line of communication and coordination between actors of PDKKH and PIASM in the ASM breeding activity can be seen in Figure 3. 


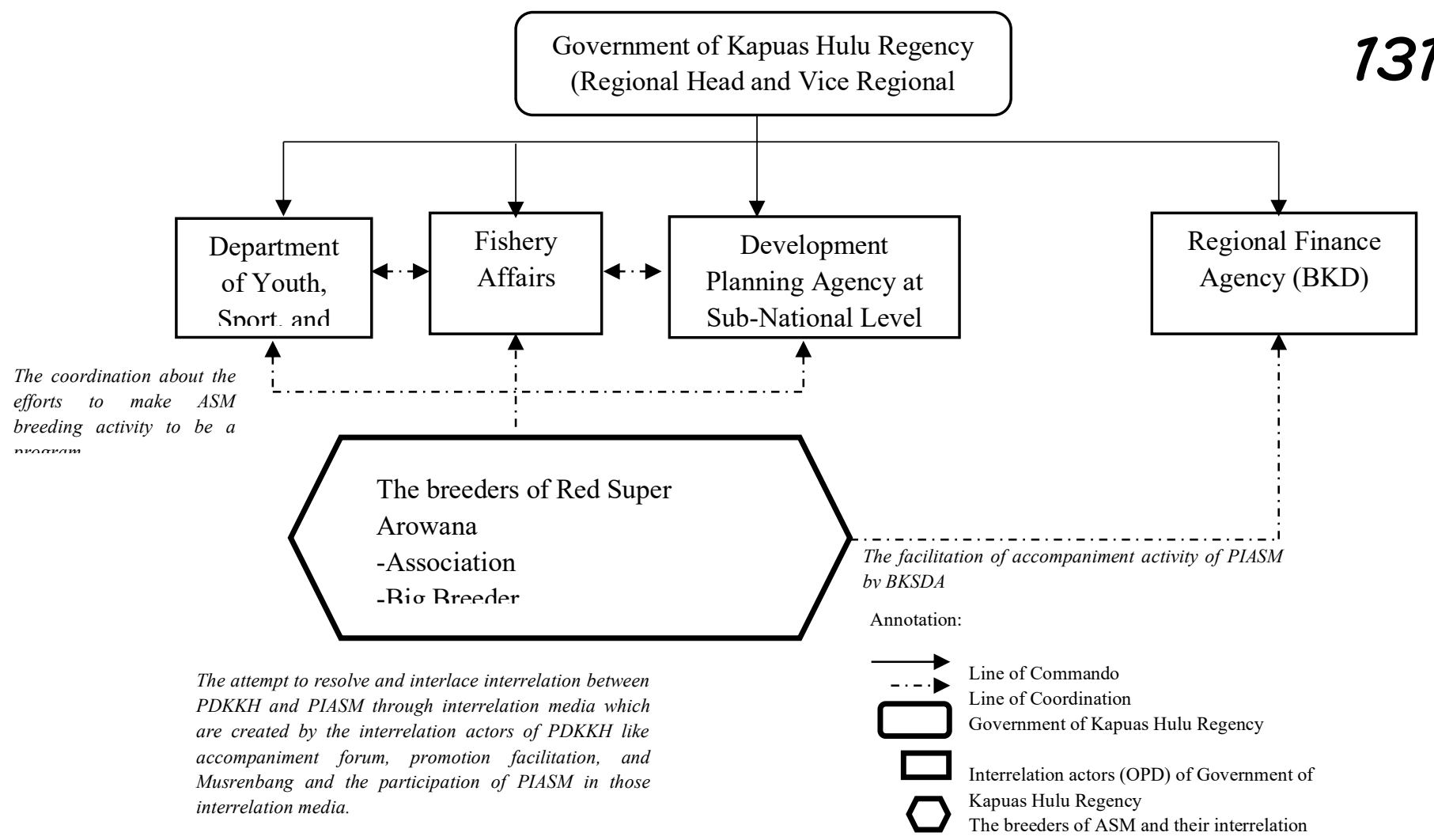

Figure 3. The line of communication and coordination between actors of PDKKH and PIASM in the ASM breeding activity. Source: Primary Data and Secondary Data, 2019
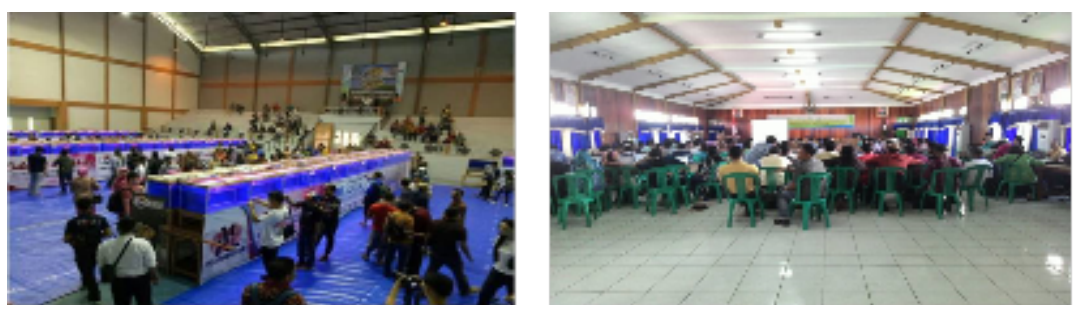

Figure 4. from left to right (a) Activity of Promotion Facilitation of ASM (Source: Infopublik.id, 2019, Musrenbang in KKH and Personal Documentation, 2019)

The research also found that on the interrelation process between PDKKH and PIASM was still found some obstacles that induced the interrelation of both parties had not been operated inclusively, equally, and fluently.

\section{Local Government Obstacles}

Authority dualism existed since Indonesia was incorporated into IUCN ((International for Conservation of Nature and Natural Resources), an organization of protection of the world's Wild Flora and Fauna (TSL) in 1975. Indonesia is obliged to adhere to the global tractate, which focuses on the protection of TSL species with endangered species category that is known as CITES (Conservation of International Trade in Endangered Species of Wild Fauna and Flora). One of the species is Red Super Arowana, and it is following Government Decision Number 43 of 1978 and Minister of Agriculture's Decree Number $716 / \mathrm{KPTS} / \mathrm{Um} / 10 / 1960$, which was underlined in Government Regulations Number 7 of 1999 About the Trade of Endangered Type of TSL. CITES also required an essential provision for Indonesia to appoint authority of manager and science that has a task to publish CITES's license in Indonesia. Based on Government Regulation Number 8 of 1999 
article 66, the Indonesia government officially appointed the Ministry of Forestry as manager authority and LIPI as science authority. At that time, the Ministry of Marine and Fisheries (KKP) had not been created. It has the management authority be not handled by the Ministry of Marine and Fisheries but supervised by the Ministry of Environment and Forestry (KLHK).

Since KKP was established in 1999 until 2014, it started to propose a transfer of authority toward AMS management, but there was still obstacle because the administration of ASM management had been bound as an official product of written State Law so that it called for numerous process and time to change the Law. This condition is the reason for authority dualism that makes KKP and its tasks executors in level II and III, Fishery Affairs of Province and Regency, cannot make the best of their role as regulator, facilitator, dynamist, and catalyst in developing the breeding activity of ASM in $\mathrm{KKH}$. The authority is still supervised by KLHK.

The quantity and status of companion officers who were not representative and the number of instructor workers whether as civil servants and contract workers that were still less, as well as the geographic barrier. There were only 9 instructors in Fishery Affairs of KHH, while the number of PIASM in KKN until 2017 reached around 1.363 breeders (Fishery Affairs of Kapuas Hulu Regency, 2018). This condition then affected the effort to improve interrelation between PDKKH and PIASM that create inadequate interrelation among both parties. The introduction of Law Number 23 of 2014 about Local Government, which contained the transfer of authority and status from all instructor workers of Fishery Affairs of KKH to Central Government (KKP), implicated on the less optimal of interrelation between PDKKH and PIASM. Besides, the other obstacles and problems still exist, like some PIASMs were challenging to be reached out because of the breadth of territory, inadequate necessary infrastructure access, and lack of transportation facility.

Sectoral ego. There was a problem in the breeding activity of ASM PDKKH, and it is the difficulty of interrelation actors to coordinate horizontally. This problem is a real consequence of ASM breeding activity as a cross-sector activity that recruited many actors as event organizers and the existence of the understanding of PDKKH interrelation actors about their duties, which only worked in the scope of main task and each function. Consequently, that sectoral ego impacted on the obstruction of improving interrelation between PDKKH and PIASM.

d) Limited budgeting capacity and allocation. Assistance for ASM breeding activity required big funds, while budgeting capacity from KKH's APBD was still not enough. The urge to develop ASM breeding activity to be a program in its budgeting negotiation process still experiences problems. The budget allocation for PDKKH OPDs was still inappropriate. There were OPDs which did not touch directly with social development programs. For example, some agencies and offices had more significant budget allocation than technical OPDs that contact directly with targeted subjects of development, such as some specific OPDs which become interrelation actors between PDKKH and PIASM. The implication of breeding activity development efforts through aids and supported facilities distribution is still insufficient. Eventually, PIASM established and purchased itself those accesses independently with an improvised budget. Consequently, PIASM is skeptical of PDKKH and less willing to interact with PDKKH. The information which should be delivered by PDKKH becomes undelivered because of the dissemination of information media that has not been well.

\section{Breeders Obstacles}

Indigenous Knowledge Phenomena. Historically, before the problem of authority dualism emerged, as a form of protection on the existence of ASM, Central Government introduced Minister of Forestry's Decree Number 716/KPTS/Um/10/1980 which was continued by Director General of PHPA's Decree Number 07/KPTS/DJ-VI/1988 about Arowana fish is categorized as Red Super Arowana (ASM) which is involved as endangered fauna. It is explicitly prohibited to be arrested and traded in without a special license of government. Those provisions were strengthened by the publication of Minister of Forestry's Decree Number 516/KPTS/II/1995 which stated the status of ASM as Appendix I, so that the species of ASM that did not only come from nature but also the result of breeding was prohibited from being traded in any forms, including its derived products. The implication was, during a period from the 1980 s to the 1990 s, the role of the central, province, and regional governments tended to be nothing. The assistance absence of the government has PIASM develop their own knowledge and competence in breeding activity. 
Nowadays, that condition above becomes an obstacle for PDKKH in resolving and interlacing the interrelation with PIASM. In implementing assistance, PDKKH is faced with a reality where PIASM had possessed unique Indigenous Knowledge, which is gained by self-taught and hereditary learning process through experiences, knowledge, and competence development independently. The measures have become guidance for PIASM in deciding decisions and overcoming problems of ASM breeding activity. For example, their understanding of procedures of broodstock spawning for PIASM which owns merely the narrow area and small capital is by partitioning the main fishpond with a net to be some small fishponds. The attempt to save energy and electricity on the technique of water drainage and feces in fishponds is by creating a fishpond inside a fishpond. A big fishpond sized 4x6 meter called tangai is excavated with 1,5-2 meter depth that functions as a habitat of fish. Afterward, in the middle of the main fishpond is dug up to create a small fishpond sized $2 \times 2$ meter with 1-meter depth and $150-200 \mathrm{~cm}$ inclination. A small fishpond is named lubuk that functions as a place of fish's feces accumulation, and it is drained through the drainage process. The other example for PIASM that owns a narrow area is by adopting a commonality strategy of agricultural land where PIASM which possesses side by side fishponds will incorporate their fishponds into one to be collectively managed. It can be seen in Figure 5 .
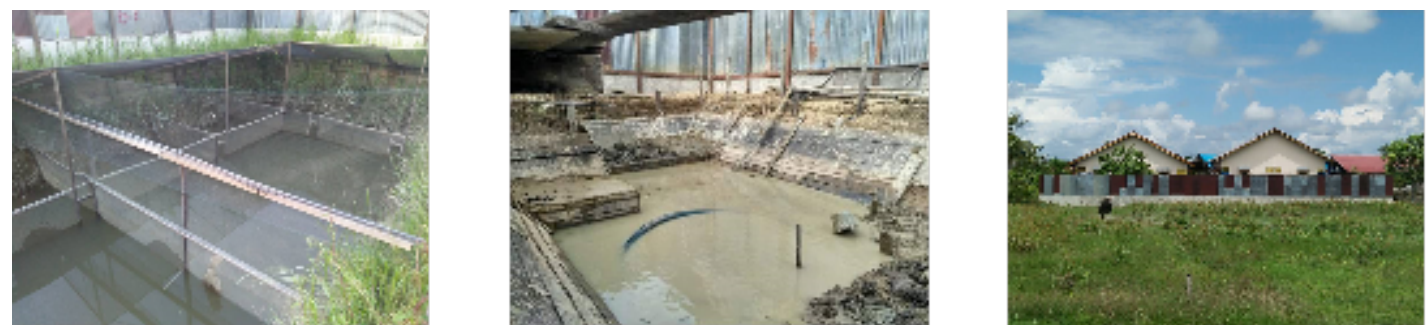

Figure 5: From left to right (a) The broodstock spawning with a net, (b) The creation of Tangai and Lubuk, and (c) The commonality system of the breeding fishpond. Source: Researcher's

Documentation, 2019.

Those facts have made PIASM more conscious about ASM technical breeding than assistance officers from PDKKH interrelation actors. The implication is that when the implementation of assistance activity held by interrelation actors of PDKHH that have been scheduled and announced, it is often found that PIASM was absence, even if there were only a few who come.

Patron-client relation. The high economic value of ASM and the information value of indigenous knowledge cause external communication forms of PIASM, which is not only exclusive to other breeding community but also centralized to the actors of breeding internal circle. The PIASM actors of big breeders who have substantial capital are easy to control sources of information, while PIASM actors from small breeders face difficulty in accessing the sources of information because the distribution process of information tends to be detained by big breeders. The lack of information access and communication interaction in the internal circle of PIASM implicate the creation of patron-client relation patterns between big breeders and small breeders. The necessity and limitation on capital and market access force clients to ask for patrons' help. This condition requires clients to sell all breeding results to the patron with unstandardized ASM's size and age and the selling price which is lower than the market place. The other implication is that the clients are required to keep all information concerning ASM breeding activity, particularly legality and market access, from the external breeding community. The forms of keeping information can be identified during ASM breeding data collection activities held by PDKKH where the data of PIASM are not entirely filled because of the limitation of communication interaction and information exchange among both parties. 


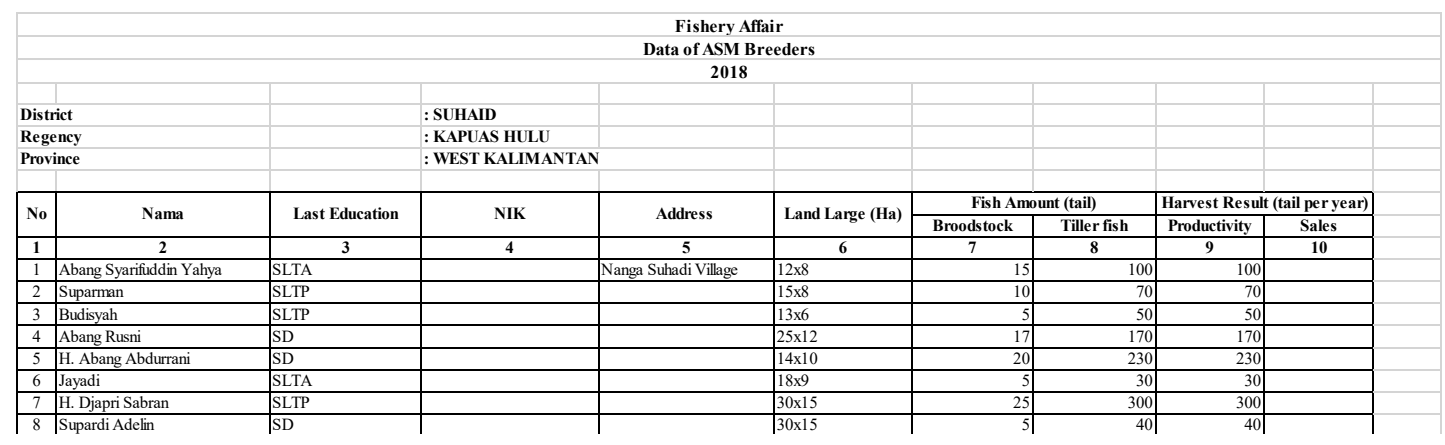

Figure 6. Data form of ASM breeders in Kapuas Hulu Regency. Source: Fishery Affairs of Kapuas Hulu Regency, 2018

We-ness local values. The creation of existence based on community sentiments -that is a sense of togetherness based on the same livelihood - has strengthened self-identification from some PIASMs in the form of we-ness understanding. The existence of we-ness makes some PIASMs more solid, maintaining fellow feelings, co-fulfilling the necessity and interest, creating compactness atmosphere is facing external's influence. Consequently, they do not consider the economic value of ASM in other markets. Some ASMs' view is how to relish breeding activity collectively among small breeders, big breeders, association, and local society that works in breeding. This view eventually makes some PIASMs tending not to care about and participate in the forums like assistance, Musrenbang, and promotion facilitation. For them, the dialog through interrelation media is too significant and beneficial. That fact also contributes to obstruction of PIASM and PDKKH efforts in resolving and interlacing the interrelation.

\section{Communication Accommodation Study of the Effort of Local Government of Kapuas Hulu Regency in Resolving and Interlacing Interrelation with Breeders}

As a condition, accommodation can refer to an equilibrium in the interaction among communication agents. As a process, accommodation is an active action or adaptation among communication agents (West and Turner, 2007). Howard Giles (2008) stated that communication accommodation relates to interpersonal or intergroup adaptation in a communication interaction based on premises which consider motivation and consequence that underline what is happening to accommodate other communication agents. Giles uttered that if a comparison is positive, it will cause a set of positive communication interactions on the communication form of communication agents as responses to interlocutors (West and Turner, 2008).

The forms of adaptation in accommodation communication consist of convergence and divergence (Giles and Tania, 2007). Convergence is the adaptation of communication behavior where communication agents are involved in interaction that adapts toward each other communicative behavior (verbally and non-verbally). Adjustment is a selective process because the choice to convergence is based on self-perception concerning interaction partners' interests. The interests consist of competence, personality, ethnic, culture, belief, comprehension, hobby, job, interest, and necessity. The higher the stakes, it is firmly possible to stimulate the convergence of the two parties (Kartikawangi, 2017). Convergence illustrates that communication interaction values positive. Divergence is a behavior adaptation where communication agents who are involved in interaction do no present the wish to adopt toward each other communication behavior (verbally and non-verbally). Divergence is not the condition to exclude responses, but it is more attempt to do disassociation toward interaction partners with some reasons like preserving social identity, culture, interest, power difference and role, interlocutors' attitude that does not pleasure or have the bad appearance (Kartikawangi, 2017). The choice of divergence describes that the quality of communication interaction values negatively.

On the ASM breeding activity, the efforts to resolve and interlace interrelation between PDKKH and PIASM have led to the form of convergence adaptation of formal-informal intergroup diagonally. The choice of convergence adaptation between PDKKH and PIASM occurs when collective interest 
is shown through dialog from both parties to make ASM breeding activity to be a program. This can be found from the existence of PDKKH's efforts to create interrelation media to implement convergence with PIASM and the form of communication behavior of PDKKH interrelation actors on those interrelation media like assistance and promotion facility which have adapted and adjusted with local cultural values or social norms that exist in PIASM's environment.

Besides, on the PIASM side, the choice on convergence adaptation can be viewed from the efforts of PIASM participation on those interrelation media in its social relationships in order to do convergence with PDKKH, and form of communication behaviour of PIASM interrelation actors on those interrelation media like Musrenbang forum and facilitation of promotion which has been adjusted with the formal situation in PDKKH's environment. The research showed that the implementation of convergence adaptation held by PDKKH with PIASM has not wholly lead to unity or mutual relationship. On the specific situation when the attempt to resolve the interrelation between PDKKH and PIASM happens, both parties also tend to use divergence adaptation. The choice of divergence adaptation between PDKKH and PIASM occurs when there is a will from both to keep information distribution respectively about ASM breeding activity. PDKKH holds back the information about all kinds of access, requirements of capital assistance request, facilities of ASM breeding activity, while PIASM keeps the information about the details of the ASM breeding technique and physical and non-physical aspects of ASM breeding activity.

As it is well known that there is a motive beyond why an individual or group chooses convergence and divergence in the interaction (Kartikawangi, 2017). The motivation behind the option of PDKKH and PIASM to do convergence is based on interests' motivation. On the one hand, the interest of PDKKH is to make ASM breeding activity as one of the sources of locally-generated revenue. On the other hand, the interest motivation of PIASM is presented by the wish to develop their ASM breeding activity to reach financial autonomy. The motive which forces PDKKH and PIASM to choose divergence is a tension motivation from those two parties' internal communication. On the PDKKH side, the pressure from the internal communication form comes from authority dualism, quantity, and status of interrelation actors, which do not support, geographical obstacles, sectorial ego, limited capacity, and allocation of budget. This then makes PDKKH in its divergence adaptation with PIASM prefers to opt divergence over accommodation. It is found from the communication behavior form of PDKKH interrelation actors in interrelation media like Murenbang which too implements top-down style, normative, dominance, and patronize in its interrelation with PIASM. On PIASM side, the pressure from the internal communication form is caused by the effort to preserve indigenous knowledge, the influence of patron-client relation, local values guidance, which is still held and comprehended negatively. This then makes PIASM in its divergence adaptation with PDKKH tend to select divergence of maintenance. It is seen from the communication behavior form of PIASM interrelation actors on interrelation media like Musrenbang and assistance, which tend to be passive, not substantive, and apply local language in its interrelation with PDKKH.

Besides, the choice on divergence held by PIASM can be valued as positive, like the attempt to protect indigenous knowledge, which is not recognized by other breeding communities and this is utilized to individual and group's interest. This is because indigenous knowledge has caused the breeding activity of PIASM still exists and survives and it inherits in the internal community of PIASM. The availability of local values is held positively in the form of we-ness comprehensions like ASM trading, which is not just for commercial purposes but for the sense of solidarity and the trading system, which only relies on consensus.

Giles and Tania (2007) uttered that adaptation intensity has a significant role in the value of positive and negative from the individual or group's option on convergence and divergence. Basically, the adaptation intensity between PDKKH and PIASM in the interrelation media could be found from a routine schedule of those media activities, but its implementation is still lack. An interrelation medium through promotion facilitation was only implemented once a year. Besides, assistance was officially scheduled 120 times in a year with a monthly average of 10-12 times. Because of the quantity lack and status change from some PDKKH interrelation actors, geographical condition influence, inadequate infrastructure, and less interest of PIASM to participation, the assistance intensity is not as many as its official schedule. The other interrelation medium is Musrenbang, which was periodically planned to be implemented three times a year, but the reality in regional scope was only realized once, and the other two were manifested in district and district so that it was impossible to involve all PIASMs. The process of information reduction in the adaptation between PDKKH and PIASM to resolve the interrelation was not well-operated. The information distribution from both 
73 parties seemed minimal, so that both parties did not do information reduction. This is because PDKKH and PIASM still show each other the information enrichment. The information reduction, which was done showed that the information distribution had been well-implemented among those parties that realize the process of interrelation. The theme of adaptation and its measurement in choosing convergence and divergence by both PDKKH and PiASM can be found in Table 1 and Table 2.

\begin{tabular}{|c|c|c|c|c|}
\hline & \multicolumn{2}{|c|}{ PDKKH } & \multicolumn{2}{|c|}{ PIASM } \\
\hline & Convergence $(+)$ & Divergence (-) & Convergence $(+)$ & Divergence (-) \\
\hline $\begin{array}{l}\text { Adaptation } \\
\text { Theme }\end{array}$ & $\begin{array}{l}\text { To make ASM } \\
\text { breeding activity to } \\
\text { be a program } \\
\text {-creating } \\
\text { interrelation media } \\
\text { with PIASM } \\
\text {-motivation to } \\
\text { choose } \\
\text { convergence is } \\
\text { based on interest }\end{array}$ & & $\begin{array}{l}\text { To make ASM } \\
\text { breeding activity to } \\
\text { be a program } \\
\text {-The effort to } \\
\text { participate in } \\
\text { interrelation media } \\
\text { in its social relation } \\
\text { with PDKKH } \\
\text {-motivation to } \\
\text { choose } \\
\text { convergence is } \\
\text { based on interest }\end{array}$ & \\
\hline $\begin{array}{l}\text { Adaptation } \\
\text { Theme }\end{array}$ & & $\begin{array}{l}\text { The effort to keep } \\
\text { information } \\
\text { distribution about } \\
\text { ASM breeding } \\
\text { activity } \\
\text {-Information } \\
\text { about access, } \\
\text { procedures of } \\
\text { requirement, } \\
\text { capital assistance } \\
\text { request and } \\
\text { facilities of ASM } \\
\text { breeding activity } \\
\text {-Motivation to opt } \\
\text { divergence is } \\
\text { pressure from } \\
\text { internal } \\
\text { communication } \\
\text { form. }\end{array}$ & & $\begin{array}{l}\text { The effort to keep } \\
\text { information } \\
\text { distribution about } \\
\text { ASM breeding } \\
\text { activity } \\
\text {-Information } \\
\text { about the details } \\
\text { of ASM breeding } \\
\text { technique and } \\
\text { physical and non- } \\
\text { physical aspects } \\
\text { of ASM breeding } \\
\text { activity } \\
\text { - Motivation to } \\
\text { opt divergence is } \\
\text { pressure from } \\
\text { internal } \\
\text { communication } \\
\text { form. }\end{array}$ \\
\hline
\end{tabular}

Table 1. Adaptation Theme for the Selection of Convergence and Divergence of PDKKH with PIASM

\section{PDKKH}

PIASM

Analysis Unit Convergence Divergence (-) $(+)$
$(+)$ 


\begin{tabular}{|c|c|c|c|c|}
\hline $\begin{array}{l}\text { Communicative } \\
\text { behavior in } \\
\text { adaptation }\end{array}$ & $\begin{array}{l}\text {-PDKKH } \\
\text { interrelation } \\
\text { actors on } \\
\text { interrelation } \\
\text { media like } \\
\text { assistance and } \\
\text { promotion } \\
\text { facilitation } \\
\text { have } \\
\text { attempted to } \\
\text { adjust with } \\
\text { local cultural } \\
\text { values or } \\
\text { social norms } \\
\text { that are held in } \\
\text { PIASM's } \\
\text { environment }\end{array}$ & $\begin{array}{l}\text {-Refers to the } \\
\text { divergence of over } \\
\text { accommodation } \\
\text { where PDKKH } \\
\text { interrelation actors } \\
\text { on interrelation } \\
\text { media implement } \\
\text { top-down style, } \\
\text { normative, } \\
\text { dominance and } \\
\text { patronize in its } \\
\text { interrelation with } \\
\text { PIASM }\end{array}$ & $\begin{array}{l}\text { - PIASM } \\
\text { interrelation } \\
\text { actors on the } \\
\text { interrelation } \\
\text { media like } \\
\text { Musrenbang } \\
\text { forum and } \\
\text { facilitation of } \\
\text { promotion } \\
\text { which has } \\
\text { been adjusted } \\
\text { with the } \\
\text { formal } \\
\text { situation in } \\
\text { PDKKH's } \\
\text { environment }\end{array}$ & $\begin{array}{l}\text {-Refers to the } \\
\text { divergence of } \\
\text { maintenance } \\
\text { where PIASM } \\
\text { interrelation actors } \\
\text { on those } \\
\text { interrelation } \\
\text { media like } \\
\text { Musrenbang } \\
\text { forum and } \\
\text { facilitation of } \\
\text { promotion which } \\
\text { tend to be passive, } \\
\text { not substantive } \\
\text { and apply local } \\
\text { language in its } \\
\text { interrelation with } \\
\text { PDKKH }\end{array}$ \\
\hline
\end{tabular}

\begin{tabular}{|c|c|c|c|c|}
\hline $\begin{array}{l}\text { Adaptation } \\
\text { Motivation }\end{array}$ & $\begin{array}{l}\text {-Will to make } \\
\text { ASM breeding } \\
\text { activity as one } \\
\text { of the sources } \\
\text { of locally- } \\
\text { generated } \\
\text { revenue }\end{array}$ & $\begin{array}{l}\text {-Pressure from the } \\
\text { internal } \\
\text { communication } \\
\text { form comes from } \\
\text { authority dualism, } \\
\text { quantity, and } \\
\text { status of } \\
\text { interrelation actors } \\
\text { which do not } \\
\text { support, } \\
\text { geographical } \\
\text { obstacles, sectorial } \\
\text { ego, limited } \\
\text { capacity and } \\
\text { allocation of } \\
\text { budget }\end{array}$ & $\begin{array}{l}\text {-Wish to } \\
\text { develop their } \\
\text { ASM breeding } \\
\text { activity to } \\
\text { reach financial } \\
\text { autonomy }\end{array}$ & $\begin{array}{l}\text {-Pressure from the } \\
\text { internal } \\
\text { communication } \\
\text { form is caused by } \\
\text { the effort to } \\
\text { preserve } \\
\text { indigenous } \\
\text { knowledge, the } \\
\text { influence of } \\
\text { patron-client } \\
\text { relation, local } \\
\text { values guidance } \\
\text { which is still held } \\
\text { and } \\
\text { comprehended } \\
\text { negatively }\end{array}$ \\
\hline
\end{tabular}

- Attempt to
protect indigenous
knowledge form
other breeding
community not to
be utilized for
their personal or
group's interest,
and it inherits for
PIASM family to
make ASM
breeding activity
survives.

- The availability of local values is held positively in the form of weness comprehensions like ASM trading which is not just for economic purpose, but for the sense of solidarity and the trading system which is just relied on consensus.

\begin{tabular}{lllll}
\hline Intensity of & -There have & -The intensity is & - There have & -The intensity is \\
Adaptation & been routine & still minimal & been routine & still minimal \\
& schedule from & because promotion & schedule from & because \\
& the & facilitation & the & promotion \\
& implemented & implemented once & implemented & facilitation \\
\hline
\end{tabular}




\begin{tabular}{|c|c|c|c|c|}
\hline 38 & $\begin{array}{l}\text { activity on } \\
\text { interrelation } \\
\text { media }\end{array}$ & $\begin{array}{l}\text { a year, assistance } \\
\text { was less than } 10 \\
\text { times per month } \\
\text { and } 120 \text { times per } \\
\text { year, Musrenbang } \\
\text { forum was just } 3 \\
\text { times a year which } \\
\text { was divided into } \\
\text { one time in } \\
\text { regency, one time } \\
\text { in district and the } \\
\text { other one in } \\
\text { village, so that not } \\
\text { all PIASM } \\
\text { participated. }\end{array}$ & $\begin{array}{l}\text { activity on } \\
\text { interrelation } \\
\text { media }\end{array}$ & $\begin{array}{l}\text { implemented once } \\
\text { a year, assistance } \\
\text { was less than } 10 \\
\text { times per month } \\
\text { and } 120 \text { times per } \\
\text { year, Musrenbang } \\
\text { forum was just } 3 \\
\text { times a year which } \\
\text { was divided into } \\
\text { one time in } \\
\text { regency, one time } \\
\text { in district and the } \\
\text { other one in } \\
\text { village, so that not } \\
\text { all PIASM } \\
\text { participated. }\end{array}$ \\
\hline $\begin{array}{l}\text { Information } \\
\text { Reduction in } \\
\text { Adaptation }\end{array}$ & & $\begin{array}{l}\text {-There is nothing } \\
\text { reduction because } \\
\text { both parties still } \\
\text { need information } \\
\text { enrichment. }\end{array}$ & & $\begin{array}{l}\text {-There is nothing } \\
\text { reduction because } \\
\text { both parties still } \\
\text { need information } \\
\text { enrichment. }\end{array}$ \\
\hline
\end{tabular}

Table 2. Measurement of Adaptation Selection in Improving PDKKH Interrelation with PIASM

From the presentation of field facts on Table 1 and 2 above, it shows that partial convergence which is done by PDKKH with PIASM in the attempt of both parties to resolve and interlace the interrelation, eventually, contribute on the weakening of the positive value of the convergence conducted by PDKKH with PIASM. On the other side, it also strengthens and enhances positive value from divergence done by PDKKH with PIASM. This is because in the adaptation process of PDKKH with PIASM, one of the parties still leads to sharpening similarity and unity and also lead to sharpening diversity and separation. Convergence situation of PDKKH with PIASM in the effort of both parties to improve and interlace the interrelation seems to be just formality. There is nothing equal position and flexibility from interrelation actors of PKKH with PIASM, both as communicator and communicant. Interrelation is not considered as a solid substance that flows up and down by PDKKH with PIASM. The implication is causing the ineffective interrelation media established by PDKKH and the participation of PIASM on those media so that this is difficult to reach collective aims and each aim from PDKKH and PIASM in ASM breeding activity, as it is presented on Figure 7. 
-ASM breeding activity is failed to be a program -ASM breeding activity is failed to be a new source of PAD
Communicator or Communicant

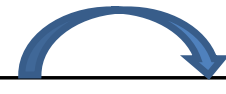

Convergence makes ASM breeding activity to be a program -Creating Interrelation Media (PDKKH) -Participation (PIASM)

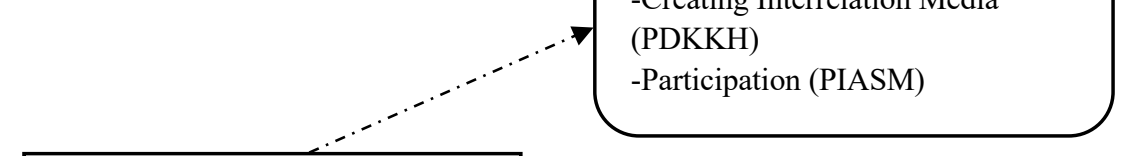

breeding activity.
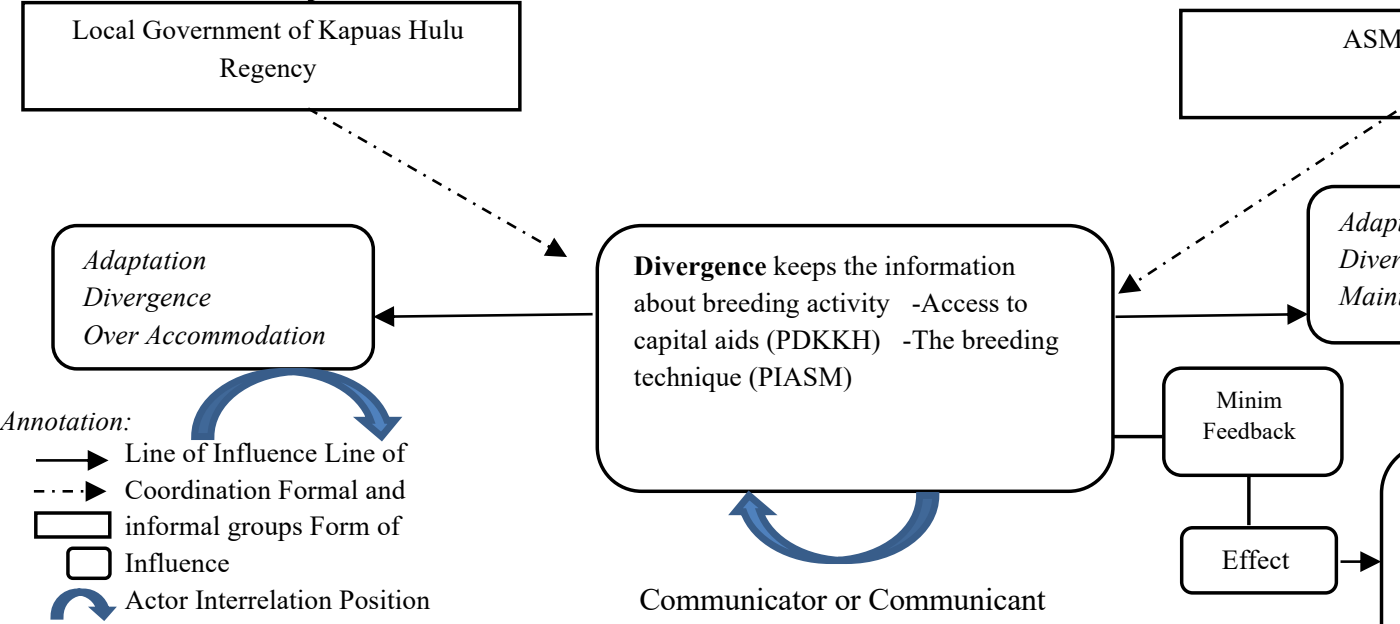

-ASM breeding activity is failed to be a program ASM breeding activity is failed to be a new source of PAD

Figure 7. Adaptation Form on the PDKKH Interrelation with PIASM

Seeing those facts, it is firmly significant to resolve the interrelation between PDKKH and PIASM to be more structured, systemic, and massive in its social relation. Formal means it is implemented with an approach that has been arranged orderly, continuity, and equality of position. Afterward, Systematic means those efforts are made collectively by all related parties. Besides, Massive means the process does not only refer to the stakeholder entity but also regard to the aspect of the routine.

The implementation of adaptation, which is convergence mutually in the process of improving the interrelation of PDKKH with PIASM, aims to achieve reliable and positive interrelation. Both parties should be able to maximize convergence process toward communication behavior, convergence motivation which leads to sharpen and unite completely, and routine intensity of convergence both from the aspect of schedule and its concrete implementation to create collective comprehension and recognition toward ASM breeding activity. Communicating development messages through dialog, mutual listening, respect for each other on the medium of interrelation can cause an understanding in terms of acceptance, interpretation, adoption, and distribution of the full information that has been and will be delivered. If accommodation communication is implemented positively through convergence adaptation, then it will emerge a set of positive communication interactions on communication behavior, motivation, interaction intensity, and information reduction toward interlocutors. It also obtained in negative value and the option on divergence adaptation (Wes and Turner, 2008). 


\section{CONCLUSION}

Inhibition in the interrelation between PDKKH and PIASM in developing ASM breeding activity to be one of the objects of economic, social, environmental and cultural development programs in the breeding community, society and regions in KKH is also influenced by the interrelation in PDKKH's internal environment with PIASM inclusively, equally, and fluently. This is because on the side of PDKHH still exists a) Authority dualism; (b) Quantity and status of assistance officers who do not support and geographical obstacles; c) Sectorial ego; (d) Limited capacity and allocation of budget. However, on the side of PIASM, there still exists a) indigenous knowledge phenomena; (b) patronclient relation in PIASM interrelation actors; c) Negative interpretation of local values.

Factually, the attempt of PDKKH with PIASM in resolving and interlacing the interrelation has been made through the creation of interrelation media like Musrenbang, assistance forum, and facilitation of promotion by PDKKH and involvement and participation of PIASM in those interrelation media. However, those efforts have not exhibited significant results. PDKKH and PIASM have not ultimately interpreted and admit ASM breeding activity as a collective activity in the integrated social sphere with the logic of sustainable socialization. Those facts then obstruct PDKKH and PIASM to realize a form of convergence adaptation wholly and mutually. The implication is causing the ineffective interrelation media established by PDKKH and the participation of PIASM on those media so that this is difficult to reach collective aims and each aim from PDKKH and PIASM in ASM breeding activity.

\section{REFERENCES}

Badan Karantina Ikan dan Pengendalian Mutu Pontianak. (2018). Laporan Tahunan 2018. Pontianak Kalimantan Barat: Badan Karantina Ikan dan Pengendalian Mutu Pontianak.

Balai Konservasi Sumber Daya Alam Provinsi Kalimantan Barat. 2018. Laporan Tahunan 2018: Capaian Rencana Kerja Program KSDAE. Kalimantan Barat: Balai Konservasi Sumber Daya Alam.

Choirul F., Siti M., Anton Y. (2018). Komunikasi Pembangunan Pemerintah Kulon Progo dalam Memberikan Pemahaman kepada Masyarakat Terkait Pembangunan New Yogyakarta Internasional Airport. Komunikator, 10(2), 140-149.

Dinas Perikanan Kabupaten Kapuas Hulu. (2018). Data Pokok. Kapuas Hulu: Dinas Perikanan.

Giles, Howard and Tania Ogay. (2007). Communication Accommodation Theory, in Explaining Communication Contemporary Theories and Exemplars. Bryan B. Whaley and Wendy Samter (ed). New Jersey: Lea.

Handaka, Tatag dan Hermin Indah Wahyuni. (2017). Interelasi Subsistem Komunikasi Pemerintah dalam Pengembangan Kambing Kaligesing di Purworejo. Jurnal Ilmu Komunikasi, 4(2), 203-220.

Hermin Indah Wahyuni. (2007). Politik Media dalam Transisi Politik: Dari Kontrol Negara Menuju Self-Regulation Mechanism. Jurnal Ilmu Komunikasi. 4(1), 11-24.

Hertanto, Sugiyanto, Safitri. (2016). Analisis Struktur Jaringan Komunikasi dan Peran Aktor dalam Penerapan Teknologi Budidaya Kentang (Petani, Kentang Desa Ngantru Kecamatan Ngantang Kabupaten Malang), Pembangunan untuk Kesejahteraan Masyarakat di Kawasan Pesisir. Jurnal Habitat, 7(2), 55-65.

http://infopublik.id/kategori/nusantara/306571/kontes-arwana-bakal-jadi-agenda-tahunan-di-kapuas -hulu?video. Diakses pada 3 Juli 2019.

Kartikawangi, D. (2013). The Implementation of Communication Acomodation. International Journal of Social Science and Humanity Studies, 5(2), 50-59.

Kartikawangi, D. (2017). Komunikasi Akomodasi dan Konvergensi Simbolis dalam Interaksi Pemangku Kepentingan. Jakarta: Universitas Atmajaya Jakarta.

Neuman, W. Lawrence. (2013). Metodologi Penelitian Sosial, Pendekatan Kualitatif dan Kuantitatif. Jakarta: PT. Indeks.

Nurdin, M. Nurmaeta, St. Tahir, M. (2014). Peran Pemerintah Daerah dalam Pemberdayaan Masyarakat Petani Jagung di Kecamatan Biringbulu Kabupaten Gowa. Otoritas Jurnal Ilmu Pemerintahan, 4(1), 66-78. 
Pandjaitan, R.H. (2015). Interelasi Manajemen Emosi Komunikasi dan Prinsip Kepatutan sebagai Jembatan Jurang Komunikasi. Jurnal Ilmu Komunikasi, 12(2), 235-250.

Rahmanto, Aris F. (2004). Peranan Komunikasi dalam Organisasi. Jurnal Komunikologi, 1(2), 5975.

Raya, Alia Bihrajihant. (2016). The Influence of Social Network Structure on the Farmer Group Participation in Indonesia. Asian Social Science, Vol. 12, No.3. Hlm 119-129.

Santosa, Imam. (2014). Pengembangan Masyarakat Berbasis Sumber Daya Lokal. Yogyakarta: Pustaka Pelajar.

Subejo. (2016). Menuju Pergeseran Paradigma Komunikasi Pembangunan Indonesia. Proceeding Seminar Nasional Lustrum II Prodi S2/S3 PKP Sekolah Pasca Sarjana. Universitas Gadjah Mada.

Undang-Undang Nomor 22 Tahun 1999. Tentang Otonomi Daerah.

Undang-Undang Nomor 25 Tahun 1999. Tentang Perimbangan Keuangan antara Pemerintah Pusat dan Daerah.

Undang-Undang Nomor 23 Tahun 2014. Tentang Pemerintah Daerah.

West Richard and Tunner Liynn. (2007). Pengantar Teori Komunikasi, Analisis, dan Aplikasi. Jakarta: Salemba Humanika.

West Richard and Tunner Liynn. (2008). Pengantar Teori Komunikasi. Penerjemah: Maria Natalia dan Damayanti Maer. Jakarta: Salemba Humanika. 